\title{
Influence of tranexamic acid in postoperative bleeding of cardiac surgery with cardiopulmonary
} bypass

\author{
Influência do ácido tranexâmico no sangramento pós-operatório de cirurgias cardíacas com circulação \\ extracorpórea
}

Flávio Donizete GONÇALVES*, Fernando Rotatori NOVAES*, Marcelo Alves MAIA*

RBCCV 44205-606

\section{Abstract}

Objective: To analyze the influence of tranexamic acid in postoperative bleeding of cardiac surgery with cardiopulmonary bypass.

Method: 51 patients who underwent heart surgery with cardiopulmonary bypass were randomly divided in 2 groups: Group I - control, with 12 coronary artery disease patients and 14 valve disease patients. Group II - Tranexamic acid, with 14 coronary artery disease patients and 11 valve disease patients. The Group I after venous access, received $250 \mathrm{ml}$ of 0.9\% normal saline solution as a placebo, Group II received 100 milligram per kilogram of body weight of tranexamic acid diluted in $250 \mathrm{ml}$ of $0.9 \%$ normal saline solution. Blood samples were taken and examined at entry to Intensive care unit and after 12, 24 and 36 hours in the postoperative period. The groups were compared concerning factors which might influence the postoperative bleeding and transfusion required: age, gender, creatinine, duration of Cardiopulmonary bypass, hematocrit, platelets and fibrinogen variations, number of saphenous vein grafts performed, mammary artery used and valve replacement or repair. The postoperative bleeding was evaluated from the $1^{\text {st }}$ to $4^{\text {th }}$ hours and the total. Data were analyzed by appropriate statistic methods (Student T-test, $\mathrm{X}^{2}$ test and Fischer's test); a p-value of less than 0.05 was the accepted level of significance.

Results: Concerning the postoperative bleeding and transfusion required, there was a statistically significant reduction in its average in valve disease patients in Group II. In coronary disease patients there was only a slight tendency. There was no significant statistical difference as far as the thromboembolic or renal complications were concerned.

Conclusion: In valve disease patients, there was a reduction in bleeding and the need of transfusions of red blood cells, both of which had statistical differences. In coronary disease patients there was only a reduced tendency. The use of tranexamic acid was not related to further thromboembolic complications or renal insufficiency in the assessed groups.

Descriptors: Tranexamic acid, therapeutic use. Cardiac surgical procedures. Fibrinogen

Work performed in the Cardiac Surgery Department of Santa Casa de Montes Claros

Presented as a dissertation for Master's degree in the Fundação Cardiovascular São Francisco de Assis - Heart Service - HSFA.

Belo Horizonte 2001

*From Santa Casa de Montes Claros 
Resumo

Objetivo: Analisar a influência do ácido tranexâmico no sangramento pós-operatório de cirurgia cardíaca com circulação extracorpórea (CEC).

Método: Foram randomizados, em 2 grupos, 51 pacientes submetidos a cirurgia cardíaca com auxílio de CEC. Grupos: Grupo I - controle, com 26 pacientes, sendo $12 \mathrm{com}$ doença coronariana obstrutiva e 14 com lesões valvulares; Grupo II ácido tranexâmico, com 25 pacientes, sendo 14 com doença coronariana obstrutiva e 11 com lesões valvulares. No grupo I foram infundidos $250 \mathrm{ml}$ de solução fisiológica (SF) $0,9 \%$, após acesso venoso; o grupo II recebeu $100 \mathrm{mg} / \mathrm{kg}$ de peso corpóreo de ácido tranexâmico diluído em $250 \mathrm{ml}$ de SF $0,9 \%$, após acesso venoso. Foram colhidas amostras de sangue para exames na admissão ao CTI, após 12, 24 e 36 horas de pós-operatório. Os grupos foram comparados com relação a fatores que pudessem influir no sangramento pós-operatório e na necessidade de hemotransfusão: idade, sexo, creatinina, tempo de CEC, variação no hematócrito, plaquetas, fibrinogênio, número de pontes safenas, uso da artéria torácica interna, troca ou reconstrução valvar. Foram avaliados o sangramento no pós-operatório da 1 a a 4 a horas e o total. $O$ método estatístico empregado foi o teste

\section{INTRODUCTION}

Despite all the efforts of researchers dedicated to the task of minimizing the deleterious effects of artificial circulation, this continues to determine numerous alterations in the organism, among which are related to hemostatia, and can cause excessive bleeding in the post-operative period [1-8].

The frequency of excessive bleeding varies between available publications depending on the definition used. An incidence of 13 to $16 \%$ was observed when abnormal bleeding was considered to be a necessity of transfusions greater than 10 units of blood in the peri-operative period. However, 5 to $7 \%$ of the patients presented with excessive bleeding when this was defined as drainage of $2000 \mathrm{ml}$ or more in the first 24 hours, as reported by DESPOTIS et al. [9]. KARSI et al. [10] on the other hand, reported an incidence of $18 \%$ of all patients submitted to surgery using cardiopulmonary bypasses (CPB), which bore a greater necessity of blood and its derivatives, increasing the risk of infection and transfusional reactions.

The use of drugs to reduce bleeding in the post-operative period of CPB assisted heart surgery has been studied since the report by MAMMEM et al. [11] with aprotinin in 1968.

Since the start of 1980, there has been growing interest in methods to minimize the exposure to blood and its derivatives in the peri-operative period, as it was discovered that HIV could be transmitted by transfusions $[1,5,12]$.

Tranexamic acid is one synthetic antifibrinolytic agent - t de Student, com correção de Welch, dependendo do caso, para os dados contínuos. Os dados categóricos (sexo, troca valvar, etc.) foram analisados pelo teste não paramétrico do $\mathrm{X}^{2}$. Em algumas situações foi usado teste exato de Fisher. Em todos os casos foi utilizado índice de significância $\mathbf{p}<0,05$.

Resultados: Com relação ao sangramento pós-operatório e a utilização de hemoderivados, houve redução da média dos mesmos nos pacientes com lesões valvulares no Grupo II, com diferença estatística. Com relação às complicações tromboembólicas ou renais, não houve diferença estatística entre os grupos.

Conclusão: Nos pacientes com lesões valvulares, ocorreu redução do sangramento e da necessidade de transfusão de concentrado de hemácias, ambos com diferença estatística. Nos pacientes com doença coronariana obstrutiva, houve apenas tendência à redução do sangramento. $O$ uso do acido tranexâmico não esteve relacionado a maior incidência de complicações tromboembólicas ou com insuficiência renal na casuística avaliada.

Descritores: Ácido tranexâmico, uso terapêutico. Procedimentos cirúrgicos cardíacos. Fibrinogênio.

it is isomer trans 4 aminoethylcyclohexanocarboxylic, abbreviated to AMCHA -, has a plasmatic half-life of 80 minutes, only $3 \%$ binds to proteins and $95 \%$ is excreted by the kidneys. The antifibrinolytic effect of tranexamic acid results from the formation of a reversible complex of the drug with the plasminogen and the plasmin that inhibit fibrinolysis, preventing the lyse of fibrin coagulation. It also acts, creating a partial block of platelet aggregation during CPB induced by the plasmin $[4,13,14]$.

\section{OBJECTIVE}

To evaluate the influence of tranexamic acid on postoperative bleeding of patients submitted to CPB assisted heart surgery.

\section{METHOD}

The study was performed in the Cardiac Surgery Department of Santa Casa de Montes Claros, in the period from February to October 2001, on 51 patients submitted to primary surgery of coronary artery bypass grafting or valve surgery.

The exclusion criteria were associated surgeries, patients using platelet anti-aggregation (within the previous 7 days), reoperations and history of blood disease. Prophylactic antibiotic therapy was performed in all patients according to the norms of the Infection Control Commission of the Hospital, with the administration of $2.0 \mathrm{~g}$ of Cephalotin, after 
venous access and at each 6 hours thereafter for 36 hours.

\section{Study Protocol}

A total of 51 patients admitted for coronary artery bypass grafting or valve surgery assisted by CPB were studied.

The study protocol was based on two randomized groups to complete this prospective research, where group I was a control group and Group II the tranexamic acid group.

Renal lesions were considered to be present when the value of creatinine was $50 \%$ higher than in the pre-operative period.

The Ethics Commission of the post graduation in the Cardiovascular Medical foundation of São Francisco de Assis, assessed this work.

\section{Group I- Control}

Sixteen male and 10 female patients with ages ranging from 15 to 70 years (mean $48.2 \pm 16.8$ ) constituted the control group. The underlying disease in 12 patients was coronary arteriosclerosis and 14 patients were suffering from valve disease, one, a double mitral-aortic injury, 4 with insufficiency, 3 with mitral stenosis, 1 aortic stenosis and 5 aortic insufficiency.

\section{Group II - Tranexamic acid}

Fourteen male and eleven female patients with ages varying from 20 to 74 years (mean $52.6 \pm 17.4$ ) made up this group. The underlying disease was coronary arteriosclerosis in 14 patients, and 11 patients had valve disease, 1 with a double aortic lesion and mitral insufficiency, 3 with aortic insufficiency, 3 with insufficiency and 4 with mitral stenosis.

Included in the protocol was the infusion of $100 \mathrm{mg} / \mathrm{kg}$ of body weight of tranexamic acid diluted in $250 \mathrm{ml}$ of $0.9 \%$ normal saline solution, immediately after venous access was achieved, for group II and in group I an infusion of $0.9 \%$ normal saline solution.

The criteria of transfusion for the patients were: hemoglobin at $9.0 \mathrm{~g} / \mathrm{dL}$ as a reference for $\mathrm{RBC}$ concentrate transfusion, alterations of $50 \%$ in the prothrombin activity or as an expander in the patients with signs of hypovolemia for plasma transfusion, platelets $<90,000 \mathrm{U} / \mathrm{mm}^{3}$ for platelet transfusion and increased bleeding with a drop in the initial value of fibrinogen for the transfusion of cryoprecipitate.

\section{METHOD}

In all patients, the following pre-operative laboratory examinations were performed: hemogram, platelet count, fibrinogen level, prothrombin activity, INR, TTPa, urea, creatinine, blood gas levels and sodium, potassium and magnesium levels.

Also coronary cineangiography was performed in coronary disease patients and in the over 35-year-old male and over 40-year-old female valve disease patients. An echocardiogram was made in all patients.

\section{Cardiopulmonary bypass technique}

A pump with rollers was used on the arterial line and membrane oxygenators with a filter on the arterial line (DMG - Equipamentos Médicos LTDA, Duque de Caxias - RJ). Myocardial protection was by anterograde hypothermic Saint Thomas-type cardioplegic solution every 20 minutes. All the patients were operated at normothermia. Heparinization was made with the intention of maintaining the activated coagulation time (ACT) greater than or equal to 480 seconds and reversal of heparin was achieved with protamine at a dose of $1: 1.3$ with an initial infusion of $1: 1$ and subsequently an infusion of 1:0.3 over four hours.

\section{Statistical Study}

Continuous data was assessed using the student T-test and, depending on the case, the correction of Welch was utilized. Categorical data were analyzed with $\mathrm{X}^{2}$ and, depending on the observed values, Yates' correction was used. In some situations, the Fisher's exact test was employed. The collected data represented non-paired samples, thus, all the tests took into consideration this fact. In all tests a p-value of less than 0.05 was considered significant.

\section{RESULTS}

There were no cases of myocardial infarction, pulmonary thromboembolism nor strokes with definitive sequels in the studied casuistic.

In Group I there was one case of kidney failure in a patient with coronary arteriosclerosis $(8.33 \%)$, case 7 and one case in the valve disease patients, $(7.14 \%)$ case 13 . In Group II there was a case of kidney failure in the coronary arteriosclerotic patients (7.14\%) and one case in the valve disease patients $(9.09 \%)$; cases 2 and 5 respectively. All these cases evolved well without the necessity of hemodialysis.

There was one reoperation case in the valve disease patients of Group I due to excessive bleeding. During the re-exploratory surgery there was no evidence of active bleeding, so only the blood clots present were removed. There were no reoperations in Group II. 
There was one death in Group II in the coronary arteriosclerotic patients (7.14\%), case 2: the patient went for an urgent surgery with cardiogenic shock. In Group I there were two deaths in the coronary arteriosclerotic patients (16.6\%), case 1 due to ARAS and case 4 because of low cardiac output. Statistical analysis did not reveal significant differences.

In relation to the variations in the mean ages, genders, body surface, ACT, platelet count, hematocrit count, creatinine levels and CPB times of the patients in the two groups, there was no significant difference. But the variations of the means of fibrinogen presented a statistical difference in the patients with coronary arteriosclerosis in the time intervals of 12 and 24 hours ( $p$-value $=0.008$ and 0.04 respectively) with a lower consumption in Group II. In the valve disease patients there was a statistical difference in variations of the PaTT means at 12 and 24 hours (p-value = 0.04 and 0.01 respectively) and in the variations of both the pre-operative and 24-hours averages of international normalized index (INR) ( $\mathrm{p}=0.02$ and 0.01 respectively) with higher values in Group I - Tables 1 and 2.

In relation to bleeding in the post-operative period measurements in $\mathrm{ml} /$ hour were made using thoracic drains in the $1^{\text {st }}, 2^{\text {nd }}, 3^{\text {rd }}$ and $4^{\text {th }}$ hours and total volume removed. The means and the standard deviation of the bleeding for the respective times and the total bleeding in Group I $(\mathrm{ml} /$ hour) in the coronary arteriosclerotic patients were: 52.1 ( \pm $69.4) ; 87.9( \pm 63.3) ; 36.7( \pm 36.5) ; 51.7( \pm 37.6) ; 541.3( \pm 275.5)$. In the valve disease patients they were from $103.6( \pm 81.9)$; $88.9( \pm 47.6) ; 60.4( \pm 53.8) ; 70.0( \pm 58.8) ; 775.4( \pm 740.0)$. In Group II, the respective means were from $84.3( \pm 109.7) ; 47.1$ $( \pm 40.0) ; 37.5( \pm 26.3) ; 37.5( \pm 30.5) ; 464.3( \pm 274.6)$ and from $54.5( \pm 40.0) ; 48.6( \pm 37.0) ; 30.0( \pm 20.4) ; 30.0( \pm 18.9) ; 407.3( \pm$ 256.1). Using the Mann-Whitman test, a significant difference was observed in the $2^{\text {nd }}$ hour $(p=0.02)$, in the $4^{\text {th }}$ hour $(p=0.01)$ and in the total blood volume $(\mathrm{p}=0.04)$ in the valve disease patients. The mean units of transfused blood per coronary arteriosclerotic patients of Group I were $275.0 \mathrm{ml}$ of RBC concentrates, $33.3 \mathrm{ml}$ of plasma, infusion of platelets was not necessary. In the coronary arteriosclerotic patients of Group II the mean units of transfused blood were $276 \mathrm{ml}$ of RBC concentrate, $71.4 \mathrm{ml}$ of plasma, infusion of platelets was not necessary. The mean units of transfused blood per valve disease patients in Group I were $514.3 \mathrm{ml}$ to RBC concentrates, $171.4 \mathrm{ml}$ of plasma and $4.28 \mathrm{U}$ of platelets. The mean units of transfused blood per patient with valve disease of Group II were $109.1 \mathrm{ml}$ of RBC concentrates, $18.2 \mathrm{ml}$ of plasma and $0.9 \mathrm{U}$ of platelets. Statistical analysis of these measurements, using the non-parametric test of Mann-
Whitney, revealed statistical significance for the volume of RBC concentrates $(p=0.04)$ in valve disease patients of Group II - Table 3 and 4.

\section{COMMENTS}

Heart surgery is traditionally associated with a high risk of transfusions of blood and its derivatives [1-3,7,14-17].

According to some authors, the main mechanisms that explain bleeding after CPB, are fibrinolysis, platelet alterations and intravascular coagulation with consumption of the coagulation factors $[1,3,6,13,18,19]$.

In this investigation a $3.0 \mathrm{mg} / \mathrm{kg}$ body weight dose of heparin was utilized as the first dose with complementary

Table 1. Comparison between the Demographic, clinical and biochemical parameters of the patients with coronary arteriosclerosis of Groups I and II.

\begin{tabular}{|c|c|c|c|}
\hline & & $\begin{array}{l}\text { Group I } \\
(\mathrm{n}=12)\end{array}$ & $\begin{array}{l}\text { Group II } \\
(\mathrm{n}=14)\end{array}$ \\
\hline Age (years) & & 59.00 & 63.71 \\
\hline \multirow[t]{2}{*}{ ACT (seconds) } & initial & 123.8 & 126.4 \\
\hline & post protamine & 160.4 & 149.9 \\
\hline \multirow[t]{5}{*}{ PaTT (seconds) } & pre-operative & 37.9 & 45.5 \\
\hline & ICU Entry & 45.3 & 42.4 \\
\hline & $\mathrm{t}-12$ & 41.3 & 48.3 \\
\hline & $\mathrm{T}-24$ & 41.9 & 46.2 \\
\hline & $\mathrm{T}-36$ & 44.8 & 43.9 \\
\hline \multirow{5}{*}{$\begin{array}{l}\text { INR } \\
\text { (seconds) }\end{array}$} & pre-operative & 1.10 & 1.12 \\
\hline & ICU Entry & 1.28 & 1.30 \\
\hline & $\mathrm{T}-12$ & 1.31 & 1.19 \\
\hline & $\mathrm{T}-24$ & 1.23 & 1.22 \\
\hline & $\mathrm{T}-36$ & 1.27 & 1.31 \\
\hline \multirow{5}{*}{$\begin{array}{l}\text { Platelets } \\
\left(\mathrm{mm}^{3} \times 1000\right)\end{array}$} & pre-operative & 212.3 & 226.6 \\
\hline & ICU Entry & 189.9 & 2.01 .1 \\
\hline & $\mathrm{T}-12$ & 182.8 & 190.3 \\
\hline & $\mathrm{T}-24$ & 168.8 & 191.1 \\
\hline & $\mathrm{T}-36$ & 163.5 & 185.2 \\
\hline \multirow{5}{*}{$\begin{array}{l}\text { Fibrinogen } \\
(\mathrm{mg} / \mathrm{dL})\end{array}$} & pre-operative & 261.1 & 269.1 \\
\hline & ICU Entry & 230.3 & 238.9 \\
\hline & $\mathrm{T}-12$ & 217.1 & $260.9^{*}$ \\
\hline & $\mathrm{T}-24$ & 259.8 & $272.9 *$ \\
\hline & $\mathrm{T}-36$ & 261.7 & 263.9 \\
\hline \multirow{5}{*}{$\begin{array}{l}\text { Hematocrit } \\
(\%)\end{array}$} & pre-operative & 43.9 & 40.8 \\
\hline & ICU Entry & 36.3 & 33.5 \\
\hline & $\mathrm{T}-12$ & 35.3 & 32.7 \\
\hline & $\mathrm{T}-24$ & 33.2 & 32.1 \\
\hline & $\mathrm{T}-36$ & 30.2 & 30.7 \\
\hline \multirow{5}{*}{$\begin{array}{l}\text { Creatinine } \\
(\mathrm{mg} / \mathrm{dL})\end{array}$} & pre-operative & 1.01 & 0.94 \\
\hline & ICU Entry & 0.86 & 0.86 \\
\hline & $\mathrm{T}-12$ & 0.99 & 1.05 \\
\hline & $\mathrm{T}-24$ & 1.10 & 1.09 \\
\hline & $\mathrm{T}-36$ & 1.03 & 0.99 \\
\hline $\begin{array}{l}\text { CPB Time } \\
\text { (minutes) }\end{array}$ & & 89.5 & 85.1 \\
\hline
\end{tabular}

$\mathrm{T}-12=12$ hours, $\mathrm{T}-24=24$ hours, $\mathrm{T}-36=36$ hours $* \mathrm{p}<0,005$ 
Table 2. Comparison between the Demographic, clinical and biochemical parameters of the patients with valve lesions of Groups I and II.

\begin{tabular}{|c|c|c|c|}
\hline & & $\begin{array}{l}\text { Group I } \\
(n=14)\end{array}$ & $\begin{array}{l}\text { Group II } \\
(n=11)\end{array}$ \\
\hline Age (years) & & 38.85 & 38.27 \\
\hline \multirow{2}{*}{ ACT (seconds) } & initial & 123.8 & 125.2 \\
\hline & post-protamine & 142.8 & 146.5 \\
\hline \multirow[t]{5}{*}{ PaTT (seconds) } & pre-operative & 42.0 & 40.8 \\
\hline & ICU Entry & 54.8 & 52.5 \\
\hline & $t-12$ & $54.1 *$ & 45.2 \\
\hline & $\mathrm{T}-24$ & $46.1^{*}$ & 40.5 \\
\hline & $\mathrm{T}-36$ & 41.9 & 41.4 \\
\hline \multirow{5}{*}{$\begin{array}{l}\text { INR } \\
\text { (seconds) }\end{array}$} & pre-operative & $1.25 *$ & 1.08 \\
\hline & ICU Entry & 1.64 & 1.59 \\
\hline & $\mathrm{T}-12$ & 1.42 & 1.26 \\
\hline & $\mathrm{T}-24$ & $1.48^{*}$ & 1.25 \\
\hline & $\mathrm{T}-36$ & 1.38 & 1.20 \\
\hline \multirow{5}{*}{$\begin{array}{l}\text { Platelets } \\
\left(\mathrm{mm}^{3} \times 1000\right)\end{array}$} & pre-operative & 224.9 & 221.9 \\
\hline & ICU Entry & 187.1 & 184.5 \\
\hline & $\mathrm{T}-12$ & 178.1 & 175.4 \\
\hline & $\mathrm{T}-24$ & 174.8 & 187.3 \\
\hline & $\mathrm{T}-36$ & 174.1 & 190.5 \\
\hline \multirow{5}{*}{$\begin{array}{l}\text { Fibrinogen } \\
(\mathrm{mg} / \mathrm{dL})\end{array}$} & pre-operative & 247.9 & 248.1 \\
\hline & ICU Entry & 196.0 & 218.2 \\
\hline & $\mathrm{T}-12$ & 233.7 & 242.7 \\
\hline & $\mathrm{T}-24$ & 260.8 & 264.3 \\
\hline & $\mathrm{T}-36$ & 254.6 & 270.8 \\
\hline \multirow{5}{*}{$\begin{array}{l}\text { Hematocrit } \\
(\%)\end{array}$} & pre-operative & 40.0 & 38.8 \\
\hline & ICU Entry & 33.6 & 36.0 \\
\hline & $\mathrm{T}-12$ & 31.5 & 33.7 \\
\hline & $\mathrm{T}-24$ & 30.6 & 31.8 \\
\hline & $\mathrm{T}-36$ & 30.7 & 30.6 \\
\hline \multirow{5}{*}{$\begin{array}{l}\text { Creatinine } \\
(\mathrm{mg} / \mathrm{dL})\end{array}$} & pre-operative & 0.85 & 0.95 \\
\hline & ICU Entry & 0.89 & 0.88 \\
\hline & $\mathrm{T}-12$ & 0.95 & 0.95 \\
\hline & $\mathrm{T}-24$ & 0.95 & 1.01 \\
\hline & $\mathrm{T}-36$ & 0.77 & 0.91 \\
\hline $\begin{array}{l}\text { CPB Time } \\
\text { (minutes) }\end{array}$ & & 76.2 & 76.6 \\
\hline
\end{tabular}

$\mathrm{T}-12=12$ hours, $\mathrm{T}-24=24$ hours, $\mathrm{T}-36=36$ hours $* \mathrm{p}<0,005$

Table 3. Comparison between the clinical parameters of bleeding and transfusion of patients suffering from coronary arteriosclerosis of Groups I and II.

\begin{tabular}{llcc}
\hline & & $\begin{array}{l}\text { Group I } \\
(\mathrm{n}=12)\end{array}$ & $\begin{array}{l}\text { Group II } \\
(\mathrm{n}=14)\end{array}$ \\
\hline $\begin{array}{l}\text { Bleeding } \\
\text { Volume } \\
(\mathrm{ml})\end{array}$ & 1st Hour & 52.1 & 84.3 \\
& 2nd Hour & 87.9 & 47.1 \\
& 3rd Hour & 36.7 & 37.5 \\
& 4th Hour & 51.7 & 37.5 \\
& $\begin{array}{l}\text { Total removed } \\
\text { by drains }\end{array}$ & 541.3 & 464.3 \\
& RBC & & \\
$\begin{array}{l}\text { Transfused } \\
\text { Volume }\end{array}$ & concentrates (ml) & 275.0 & 278.6 \\
& Plasma (ml) & 33.3 & 71.4 \\
& Platelets (U) & - & - \\
\hline
\end{tabular}

Table 4. Comparison between the clinical parameters of bleeding and transfusion of patients suffering from valve lesions of Groups I and II.

\begin{tabular}{llcc}
\hline & & $\begin{array}{l}\text { Group I } \\
(\mathrm{n}=14)\end{array}$ & $\begin{array}{l}\text { Group II } \\
(\mathrm{n}=11)\end{array}$ \\
\hline $\begin{array}{l}\text { Bleeding } \\
\text { Volume } \\
(\mathrm{ml})\end{array}$ & 1st Hour & 103.6 & 54.5 \\
& 2nd Hour & $88.9^{*}$ & 48.6 \\
& 3rd Hour & 60.4 & 30.0 \\
& 4th Hour & $70.0^{*}$ & 30.0 \\
& $\begin{array}{l}\text { Total removed } \\
\text { by drains }\end{array}$ & $775.4^{*}$ & 407.3 \\
& RBC & & \\
Transfused & concentrates (ml) & $514.3 *$ & 109.1 \\
& Plasma (ml) & 171.1 & 18.2 \\
& Platelets (U) & 4.61 & 6.7 \\
\hline $\mathrm{p}<0,05$. & & &
\end{tabular}

doses at 30 minute intervals of $\mathrm{CPB}$ with the aim of maintaining the ACT $>480$ seconds.

Several factors are implicated in the alterations in coagulation: surgical causes, heparin rebound, complementary activation, hyperfibrinolysis and platelet dysfunction. [13,20]. Previous studies demonstrated that platelet dysfunction and the excessive fibrinolysis are the most common non-surgical causes [2,3,21]; contact of blood with the non-endothelium surface of the CPB activates the coagulation system, fibrinolysis and platelets $[7,19,20,22,23]$.

To neutralize the heparin rebound effect, which occurs in the first hours of the post-operative period, as a cause of increased bleeding, the total dose of protamine $(1: 1.3)$ was divided in 1:1 diluted in $100 \mathrm{ml}$ of $0.9 \%$ normal saline solution infused drop-by-drop. The remaining 1:0.3 of protamine was infused diluted in $100 \mathrm{ml}$ of $0.9 \%$ normal saline solution in the infusion pump in a four hour period in both groups.

The increase in the morbidity and the mortality caused by increased bleeding led to the realization of this study with tranexamic acid; chosen because of the ease of use and its low cost. Because of the liberation of plasminogen activators at the start of the incision phase of the skin, we decided to begin tranexamic acid administration soon after venous access was achieved, so its peak of action would occur during the sternotomy and during the period of CPB $[3,18]$.

PUGH \& WIELOGORSKI [19], in a prospective study, 
comparing tranexamic acid with low doses of aprotinin, concluded that tranexamic acid presented the same efficiency to aprotinin when compared with placebos in patients submitted to the first heart surgery. MAINERI et al. [7], studied 48 patients randomly divided in two groups, 1 using epsilon-aminocaproic acid and the other tranexamic acid, reported that there was no statistical difference in the two groups in relation to bleeding in the post-operative period or in the necessity of transfusion of blood or derivatives. There were no events related to hypercoagulation; fibrinolysis was effectively inhibited and there was no excessive bleeding in the two groups. They concluded that both tranexamic acid and epsilon-aminocaproic acid can be safely used to control fibrinolysis and bleeding in surgeries with CBP.

In this investigation, data referring to age, gender, body surface, number of coronary and valve disease patients, utilization or not of internal thoracic artery, the number of saphenous vein grafts performed, valve replacement or reconstruction surgeries, CPB time did not present significant variations, which demonstrated that the groups were comparable.

In this study, partial hemodilution was used in the two groups, where in Group I, a reduction in the average fibrinogen of $11.8 \%$ in the coronary arteriosclerotic patients and $20.94 \%$ in the valve disease patients was seen at entry to the ICU. In Group II the reduction was of $11.23 \%$ and $12.06 \%$ for the coronary arteriosclerotic patients and valve disease patients respectively. The variation in the platelets averages, as well as hematocrit mean variations, due to transfusions of RBC concentrates and platelets, did not experience statistically significant differences except for those of the coronary patients at entry to ICU ( $p=0.03$ ).

In relation to bleeding in the post-operative period of heart surgery using CPB, DUNN \& GOA [14] concluded that tranexamic acid is useful in a reduction of from 29 to $54 \%$ when compared with a placebo. PUGH \& WIELOGORSSHI [19] reported a loss of $1000 \mathrm{ml}$ on average in patients submitted to the first surgery, concluding that effective methods to minimize this loss would be beneficial.

In this work the post-operative bleeding was studied. Due to the fact that hemodynamic instability is more frequent in the first hours, the investigation was concentrated in the initial four post-operative hours, from when, in general, stabilization in the drainage occurs. Only in the first and third hours the average bleeding in patients submitted to coronary artery bypass grafting of Group II was greater than the bleeding in the patients of Group I (52.1 vs. $84.3 \mathrm{ml}$ and $36.7 \mathrm{vs} .37 .5 \mathrm{ml}$ for $1^{\text {st }}$ and $3^{\text {rd }}$ hours respectively). At the other times, they were lower both for patients submitted to coronary grafting procedures and for valve surgery. This resulted in a final drainage mean lower in Group II; with significant difference for valve disease patients with $\mathrm{p}=$ $0.04(775.4 \mathrm{ml}$ vs. $407.3 \mathrm{ml}$ ). These results support those of WONG et al. [8], who evaluated 80 patients submitted to heart surgery with high risk of bleeding in a double-blind random study using high doses of aprotinin or tranexamic acid.

In the patients who underwent coronary artery bypass grafting in particular, the tendency of reduced bleeding is in accordance with the studies by VARGAS et al. [20] and by COUTO et al. [21]. In both investigations the same quantities of tranexamic acid were used although with different surgical durations.

The mean reduction of post-operative bleeding of the patients of Group II submitted to valve surgeries reflected directly in the reduction of average RBC concentrates transfused when compared to Group I (541.3 vs. 109.1) with a statistically significant difference $(p=0.04)$, consistent with the results of GEROMETTA et al. [24].

An important point is about the safety of using antifibrinolytic drugs which refers to the risk of thrombosis, particularly with venous grafts. MAINERI et al. [7] reported not having any negative events related to hypercoagulability. CASATI et al. [2] reported the same incidence of perioperative infarction with the use of aprotinin and tranexamic acid (2\%). WESTABY \& KATSUMATA [25] reported a greater incidence of occlusion of smaller caliber venous grafts (15.4 aprotinin group vs. 10.9 control group). Incomplete coronary artery bypass grafting due to early occlusion of the grafts can lead to late myocardial infarction and recurrent angina of the patient and reduce the eventfree time suggesting the necessity of precautions with the utilization of aprotinin.

In relation to the presented complications, there were no significant variations associated to cases of acute perioperative myocardial infarction, pulmonary thromboembolism or stroke with definitive sequels in the study group.

The routine use of tranexamic acid in heart surgery with CPB still requires further studies with greater numbers of patients to establish its clinical application and a better observation of the possible side effects.

\section{CONCLUSION}

- The use of tranexamic acid, in patients submitted to valve surgeries, determined a reduction of bleeding and a decrease 
in the RBC concentrate transfusions. In patients submitted to coronary artery bypass grafting, there was only a reduced tendency of bleeding.

- The utilization of tranexamic acid did not increase the incidence of thromboembolic complications or kidney failure.

\section{BIBLIOGRAPHIC REFERENCES}

1. Casati V, Guzzon D, Oppizzi M, Bellotti F, Franco A, Gerli C et al. Tranexamic acid compared with high-dose aprotinin in primary elective heart operations: effects on perioperative bleeding and allogeneic transfusions. J Thorac Cardiovasc Surg 2000; 120: 520-7.

2. Casati V, Guzzon D, Oppizzi M, Cossolini M, Torri G, Calori $\mathrm{G}$ et al. Hemostatic effects of aprotinin, tranexamic acid and epsilon-aminocaproic acid in primary cardiac surgery. Ann Thorac Surg 1999; 68: 2252-7.

3. Horrow JC, Hlavacek J, Strong MD, Collier W, Brodsky I, Goldman SM et al. Prophylactic tranexamic acid decreases bleeding after cardiac operations. J Thorac Cardiovasc Surg 1990; 99: 70-4.

4. Gardenal N. Influência do dipiridamol na contagem de plaquetas, no sangramento e na necessidade de hemoderivados, no pós-operatório de cirurgia cardíaca com circulação extracorpórea. [Dissertação de mestrado]. Belo Horizonte: Fundação Cardiovascular São Francisco de Assis, 2000. 75 p.

5. Hardy JF, Bélisle S. Natural and synthetic antifibrinolytics: inert, poisonous or therapeutic agents? Can J Anaesth 1997; 44: 913-7.

6. Gorman RC, Ziats N, Rao AK, Gikakis N, Sun L, Khan $\mathrm{MM}$ et al. Surface-bound heparin fails to reduce thrombin formation during clinical cardiopulmonary bypass. J Thorac Cardiovasc Surg 1996; 111: 1-12.

7. Maineri P, Covaia G, Realini M, Caccia G, Ucussich E, Luraschi $\mathrm{M}$ et al. Postoperative bleeding after coronary revascularization: comparison between tranexamic acid and epsilon-aminocaproic acid. Minerva Cardioangiol 2000; 48: 155-60.

8. Wong BI, McLean RF, Fremes SE, Deemar KA, Harrington EM, Christakis GT et al. Aprotinin and tranexamic acid for high transfusion risk cardiac surgery. Ann Thorac Surg 2000; 69: 808-16.
9. Despotis GJ, Skubas NJ, Goodnough LT. Optimal management of bleeding and transfusion in patients undergoing cardiac surgery. Semin Thorac Cardiovasc Surg 1999; 11: 84-104.

10. Karski JM, Dowd NP, Joiner R, Carroll J, Peniston C, Bailey $\mathrm{K}$ et al. The effect of three different doses of tranexamic acid on blood loss after cardiac surgery with mild systemic hypothermia (32o C). J Cardiothorac Vasc Anesth 1988; 12: 642-6.

11. Nammen EF, Thal AP, Katz W. Aplicação do trasylol na circulação extracorpórea. Rev Bras Med 1968; 25: 483-7.

12. Graham ID, Fergusson D, McAuley L, Laupacis A. The use of technologies to minimize exposure to perioperative allogeneic blood transfusion in elective surgery: a survey of Canadian hospitals. Int J Technol Assess Health Care 2000; 16: $228-41$.

13. Reid RW, Zimmerman AA, Laussen PC, Mayer JE, Gorlin JB, Burrows FA. The efficacy of tranexamic acid versus placebo in decreasing blood loss in pediatric patients undergoing repeat cardiac surgery. Anesth Analg 1997; 84: 990-6.

14. Dunn CJ, Goa KL. Tranexamic acid: a review of its use in surgery and other indications. Drugs 1999; 57: 1005-32.

15. Taylor KM. Perioperative approaches to coagulation defects. Ann Thorac Surg 1993; 56(5suppl): S78-82.

16. Nuttall GA, Oliver WC, Ereth MH, Santrach PJ, Bryant SC, Orszulak TA et al. Comparison of blood-conservation strategies in cardiac surgery patients at high risk for bleeding. Anesthesiology 2000; 92: 674-82.

17. Jamieson WR, Dryden PJ, O'Connor JP, Sadeghi H, Ansley DM, Merrick PM. Beneficial effect of both tranexamic acid and aprotinin on blood loss reduction in reoperative valve replacement surgery. Circulation 1997; 96(9 suppl): II96-101.

18. Hardy JF, Desroches J. Natural and synthetic antifibrinolytics in cardiac surgery. Can J Anaesth 1992; 39: 353-65.

19. Pugh SC, Wielogorski AK. A comparison of the effects of tranexamic acid and low-dose aprotinin on blood loss and homologous blood usage in patients undergoing cardiac surgery. J Cardiothorac Vasc Anesth 1995; 9: 240-4.

20. Vargas GF, Branco JNR, Guimarães AHS, Kobata C, Silva ETVF, Teles CA et al. Ácido tranexâmico e hemostasia em cirurgia de revascularização do miocárdio com circulação extracorpórea. Rev Bras Cir Cardiovasc 1992; 7: 272-82.

21. Couto WJ, Gregori Jr F, Cordeiro CO, Silva SS, Ketzer JL, Silva L et al. Emprego do ácido tranexâmico para controle de sangramento em cirurgia de revascularização miocárdica. Arq Bras Cardiol 1994; 63: 485-7. 
22. Gomes OM. Alterações da coagulação sangüínea em cirurgia cardíaca com circulação extracorpórea. In: Gomes OM, editor. Circulação extracorpórea. 2a ed. Volta Redonda,1985. p.57-75.

23. Dietrich W. Reducing thrombin formation during cardiopulmonary bypass: is there a benefit of the additional anticoagulant action of aprotinin? J Cardiovasc Pharmacol 1966; $27:$ 50-7.
24. Gerometta P, Antona C, Parolari A, Fratto P, Alamanni F, Spirito R, Arena V et al.- Retrospective study of the efficacy of aprotinin in heart valve surgery in adults. Minerva Cardioangiol 1995; 43: 47-54.

25. Westaby S, Katsumata T. Aprotinin and vein graft occlusion: the controversy continues. J Thorac Cardiovasc Surg 1988; 116: 731-3. 